
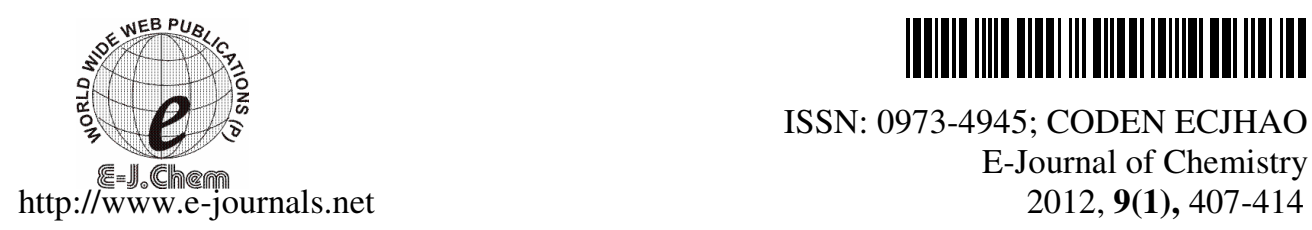

ISSN: 0973-4945; CODEN ECJHAO

E-Journal of Chemistry 2012, 9(1), 407-414

\title{
An Efficient One-Pot Synthesis of 1, 5-Benzodiazepine Derivatives Catalyzed by TBAB under Mild Conditions
}

\author{
MOHAMMAD A BASEER and ASGAR JAFAR KHAN* \\ Organic Chemistry Research Laboratory \\ Yeshwant Mahavidyalaya, Nanded-431602, India \\ *Laboratory of Organic Synthesis \\ Milliya College, Beed-431122, India \\ khan_asgar@yahoo.com
}

Received 18 June 2010; Accepted 1 March 2011

\begin{abstract}
Dihydro-1H-1,5-benzodiazepines were synthesized by reaction of $o$-phenylenediamine with ketones (acyclic / cyclic) under solvent free conditions in the presence of tetra butyl ammonium bromide (TBAB) in short reaction time with excellent yield.
\end{abstract}

Keywords: Tetra butyl ammonium bromide, 1, 5-Benzodiazepine, o-Phenylenediamine, Ketones, Short reaction time

\section{Introduction}

Benzodiazepines and their derivatives are important class of nitrogen containing heterocyclic compounds because of their pharmacological properties ${ }^{1}$. So many members of this family are nowadays mostly used as anti-anxiety, anti-inflammatory, tranquilizing, anticonvulsant, anti-depressive, anti-bacterial, analgesic, sedative and hypnotic agents ${ }^{2}$. The first benzodiazepine was introduced as a drug nearly thirty years before ${ }^{3}$. They are also used against viral disease and cardiovascular disorder ${ }^{4}$. Some benzodiazepine derivatives are used in fine chemical industries such as photographical dyes for acrylic fiber ${ }^{5}$ they are used as a valuable synthons for the synthesis of fused ring benzodiazepines class of compounds like triazolo, oxadiazolo, oxazino and furano-benzodiazepines ${ }^{6}$ due to their wide demand they have received a great attention of different chemist. According to the literature survey several synthetic methodology have been introduced for the synthesis of benzodiazepines, these include condensation of $o$-phenylenediamine with $\alpha-\beta$ unsaturated carbonyl compounds ${ }^{7}, \beta$ haloketones ${ }^{8}$ or ketones in the presence various catalyst such as $\mathrm{BF}_{3} \mathrm{OEt}^{9}$, $\mathrm{NaBH}_{4}{ }^{10}, \mathrm{PPA}-\mathrm{SiO}_{2}{ }^{11}, \mathrm{MgO}-\mathrm{POCl}{ }_{3}{ }^{12}, \mathrm{Yb}(\mathrm{OTf})_{3}{ }^{13}$, amberlyst- $15^{14}, \mathrm{Ag}_{3} \mathrm{PW}_{12} \mathrm{O}_{40}{ }^{15}$, solid 
super acid sulphated zirconia ${ }^{16}$, acetic acid - under $\mathrm{MWI}^{17}, \mathrm{AgNO}_{3}{ }^{18}$, zinc montmorilonite as catalyst at r.t ${ }^{19}$ and ionic liquid ${ }^{20,21}$. However these methodologies have several disadvantages such as harsh reaction condition, long reaction time, expensive reagents, low yield, tedious workup and formation of side products. Keeping in mind in the present study we have develop a one pot synthesis of 1, 5-benzodiazepines by condensation of $o$-phenylenediamine with ketones under mild conditions catalyzed by tetrabutylammonium bromide (Scheme 1).

\section{Experimental}

A mixture of $o$-phenylenediamine $(10 \mathrm{mmole})$, ketones $(20 \mathrm{mmole})$ and phase transfer catalyst TBAB (catalytic amount) was reflux for $50 \mathrm{~min}$ in ethyl alcohol $(10 \mathrm{~mL})$ at $60{ }^{\circ} \mathrm{C}$, after completion of reaction (monitored by TLC) the reaction mixture was cooled and poured on crushed ice, extracted from ethyl acetate $(30 \mathrm{~mL})$ and washed with water and brine $(20 \mathrm{~mL}$ each). The solvent was removed by distillation under reduced pressure. The crude product was purified by column chromatography (eluent, ethyl acetate - pet-ether). The corresponding 1, 5 benzodiazepines and fused ring benzodiazepine derivatives were obtained in $85-95 \%$ yield.

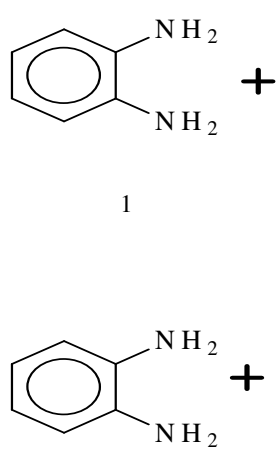

1<smiles>[R]C(C)=O</smiles>

2<smiles>O=C1CCCCC1</smiles>

2

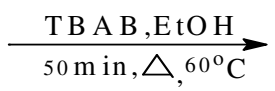

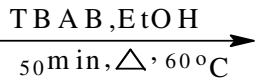

Scheme 1

\section{Characterizations}

All $\mathrm{H}^{1}$ NMR spectra were recorded in $\mathrm{CDCl}_{3}$ on a Brucker AC 200 and Brucker MSL 300 spectrometers and chemical shift were reported in ppm downfield from tetra methyl silane. Infrared spectra were recorded on a PerkinElmer infra red spectrophotometer using $\mathrm{KBr}$ discs, TLC was performed on silica gel coated aluminum plates using ethyl acetate and pet ether $(3: 7 \mathrm{v} / \mathrm{v})$ as eluent, melting points were determined on an electronic melting point apparatus and were uncorrected.

\section{Results and Discussion}

Tetrabutylammonium bromide (TBAB) is a cheap and readily available reagent it efficiently catalyze the condensation of ketones with $o$-phenylenediamine at $60{ }^{\circ} \mathrm{C}$, under mild conditions, in short reaction time $(50 \mathrm{~min})$ with excellent yield of the product. In the present study, $o$-phenylenediamine, cyclic /acyclic ketones and catalytic amount of TBAB were reflux at $60{ }^{\circ} \mathrm{C}$ in $10 \mathrm{~mL}$ ethyl alcohol after completion of the reaction (monitored by TLC) the series of corresponding 1,5 benzodiazepines and fused ring benzodiazepine derivatives were 
obtained in $85-95 \%$ yield. Whereas the yield is comparatively lower in presence of other PTC such as tricaprilmethylammonium chloride (Aliquat-336) and triethylbenzylammonium chloride (TEBA) etc. The results are summarized in Table 1. The structures of the synthesized compounds were established by their mp, IR and $\mathrm{H}^{1} \mathrm{NMR}$ spectroscopy. The ${ }^{1} \mathrm{H}$ NMR and IR spectrum of selected compounds (3a, 3d, 3f, 3g and 3i) obtained are shown in the Figures $1-7$ respectively.

Table 1. TBAB-catalyzed synthesis of 1, 5-benzodiazepines under mild conditions

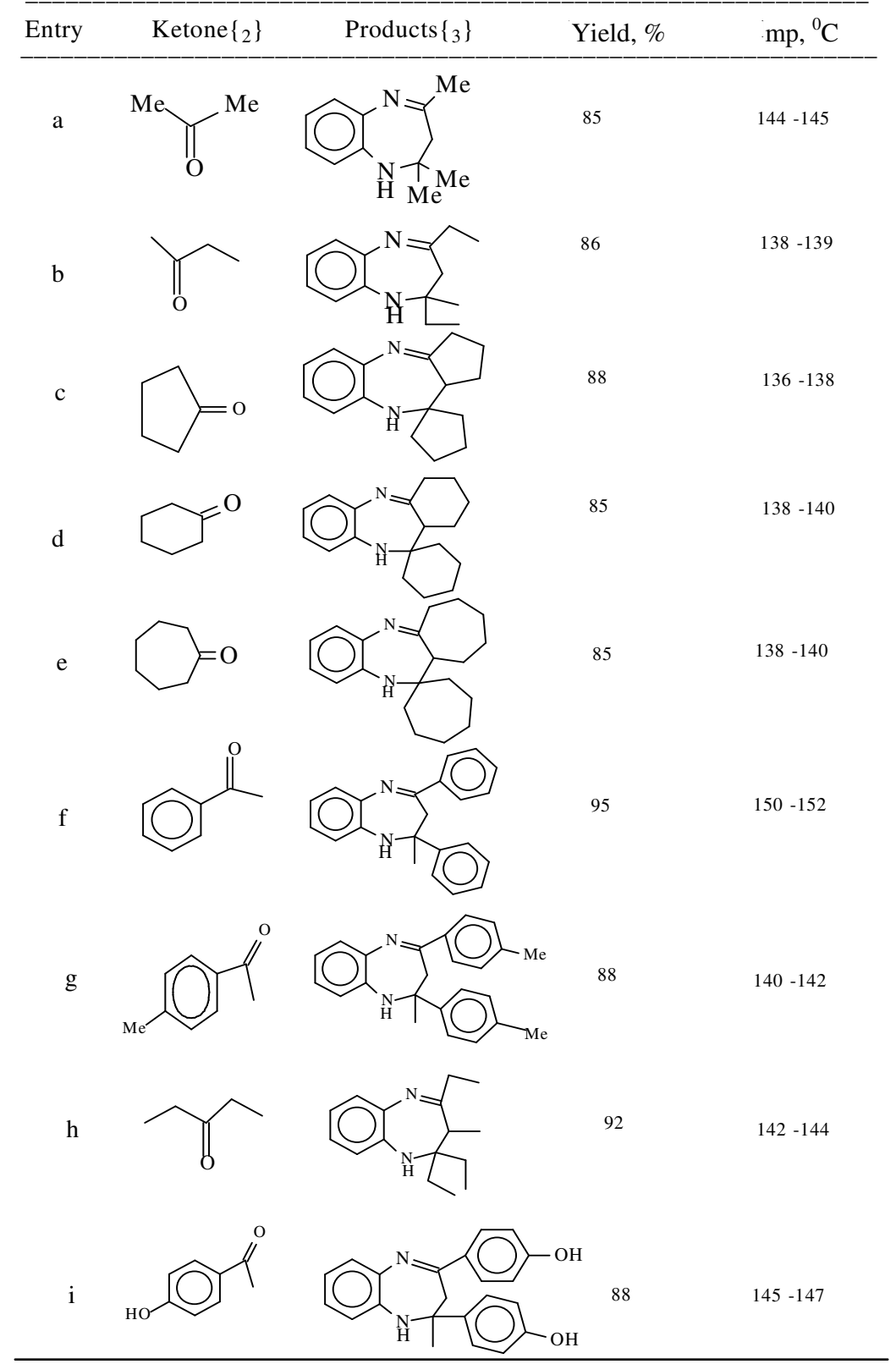




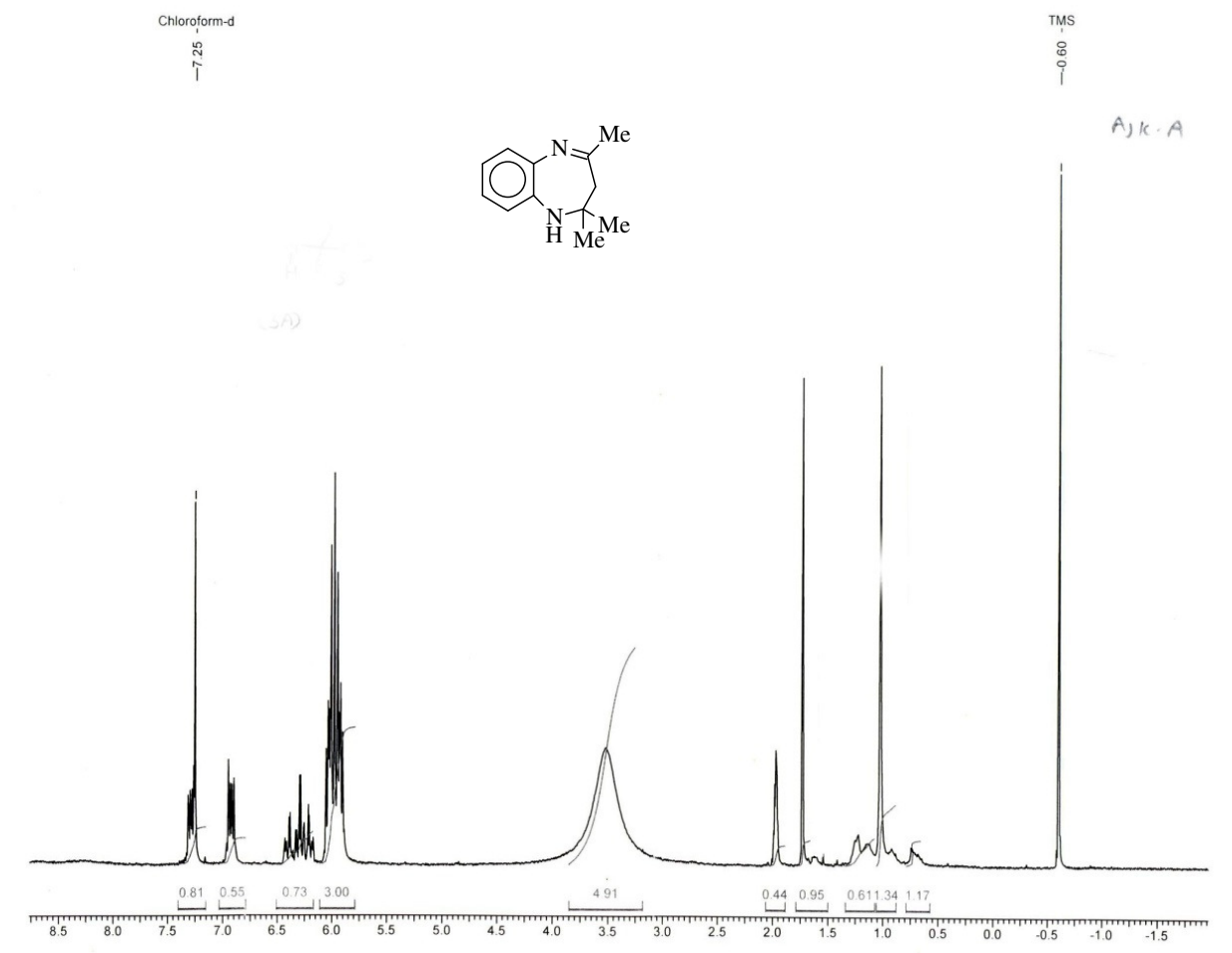

(A)

Figure 1. ${ }^{1} \mathrm{H}$ NMR spectra of (3a)

Ф SHIMADZU

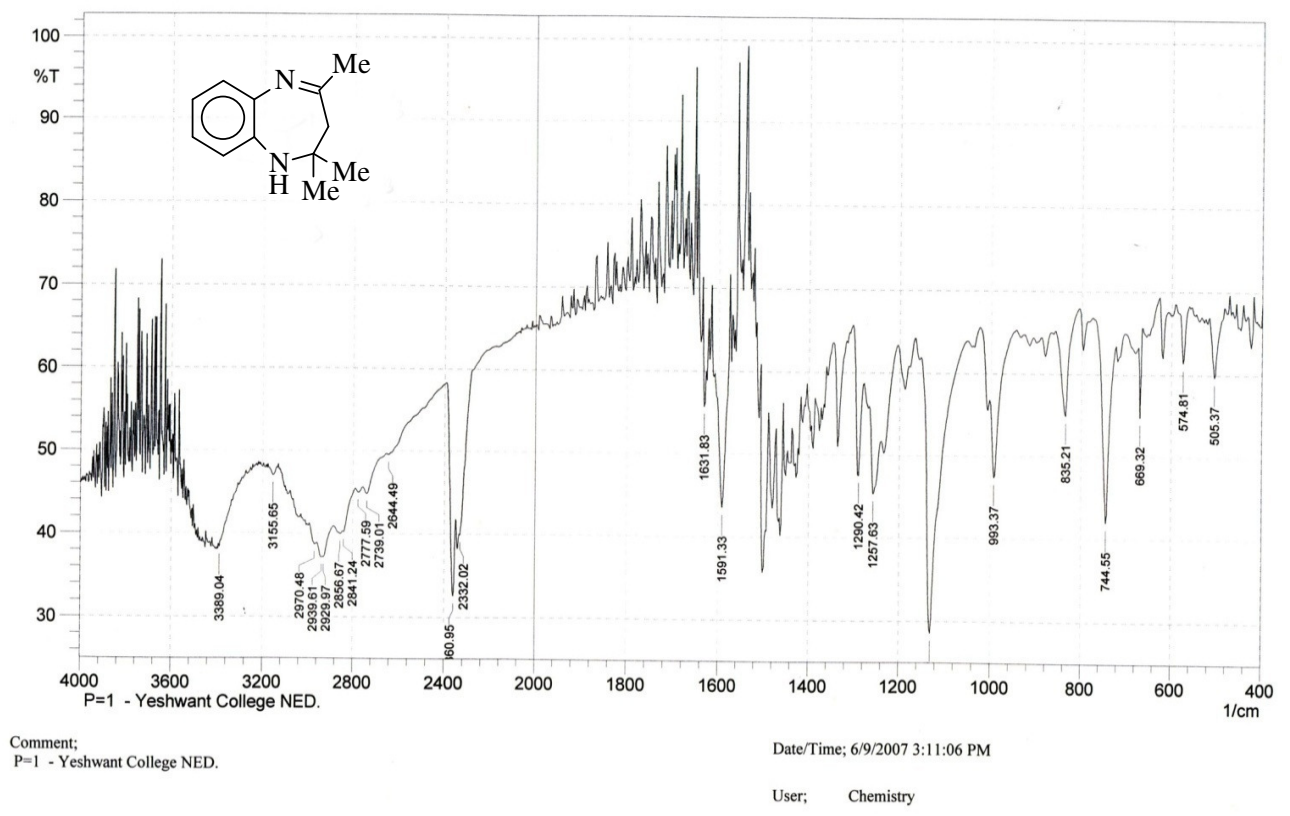

Figure 2. IR spectra of (3a) 


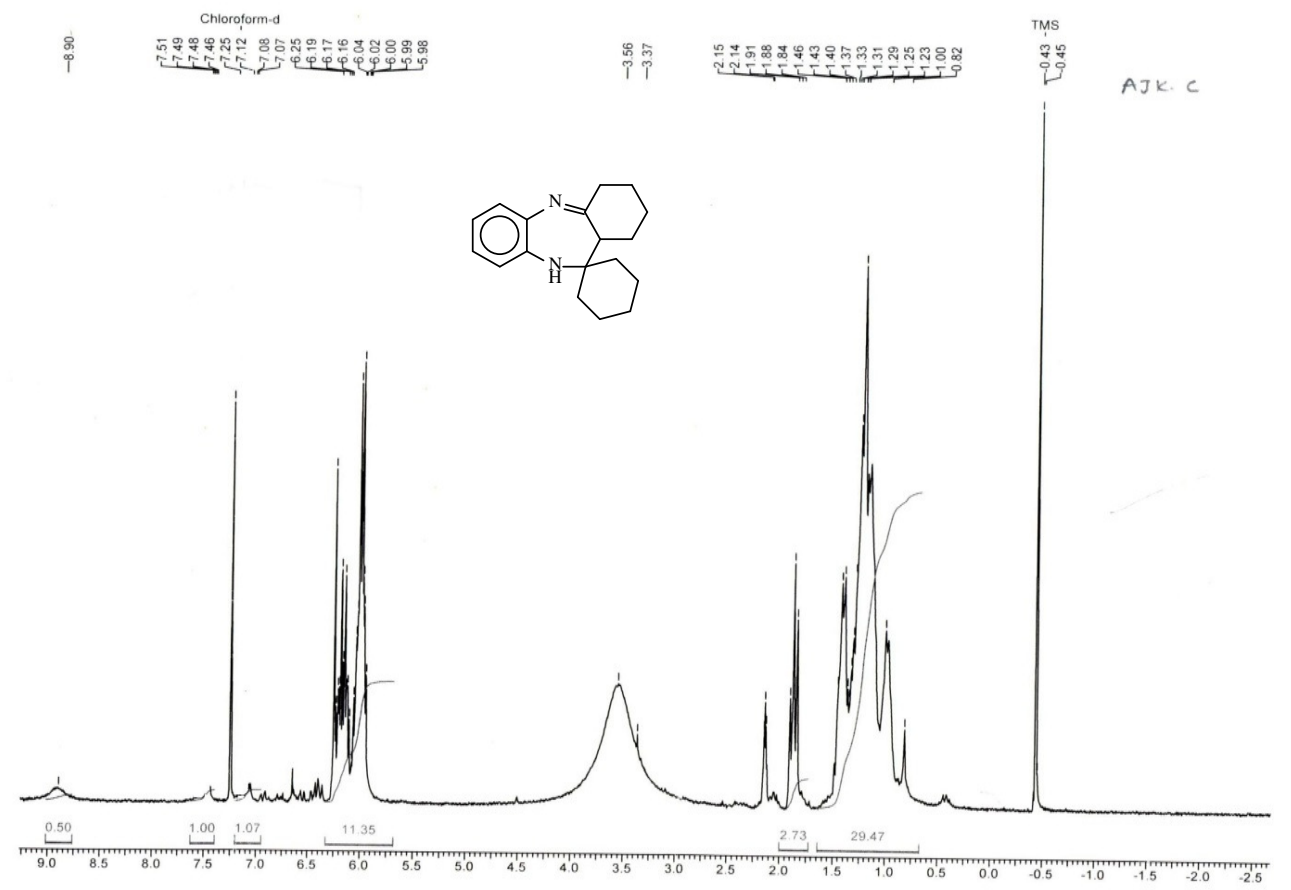

Figure 3. ${ }^{1} \mathrm{H}$ NMR spectra of (3d)

ФSHIMADZU

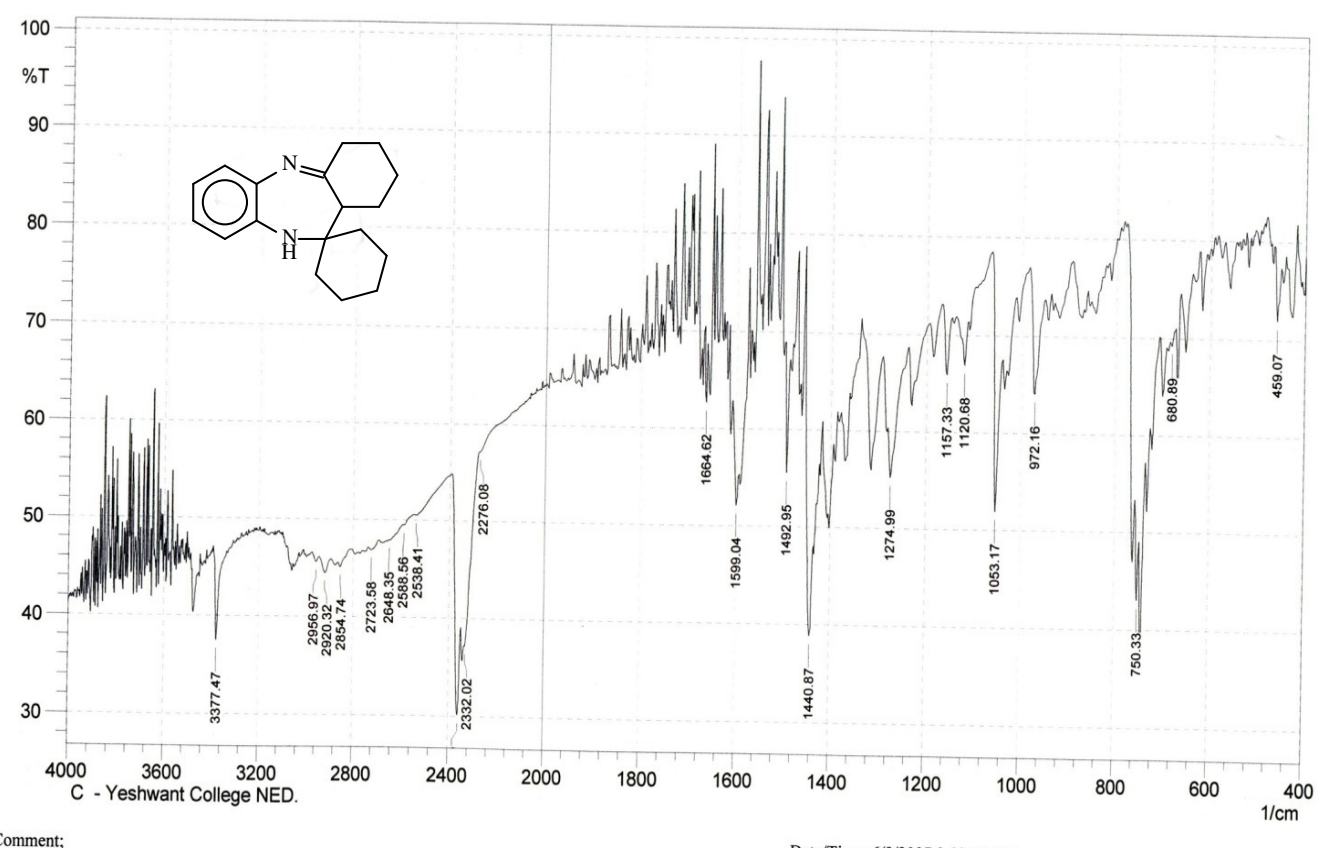

C - Yeshwant College NED.

Date/Time; 6/9/2007 3:03:56 PM

Figure 4. IR spectra of (3d) 
Chloroform-d

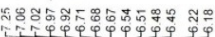

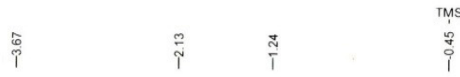
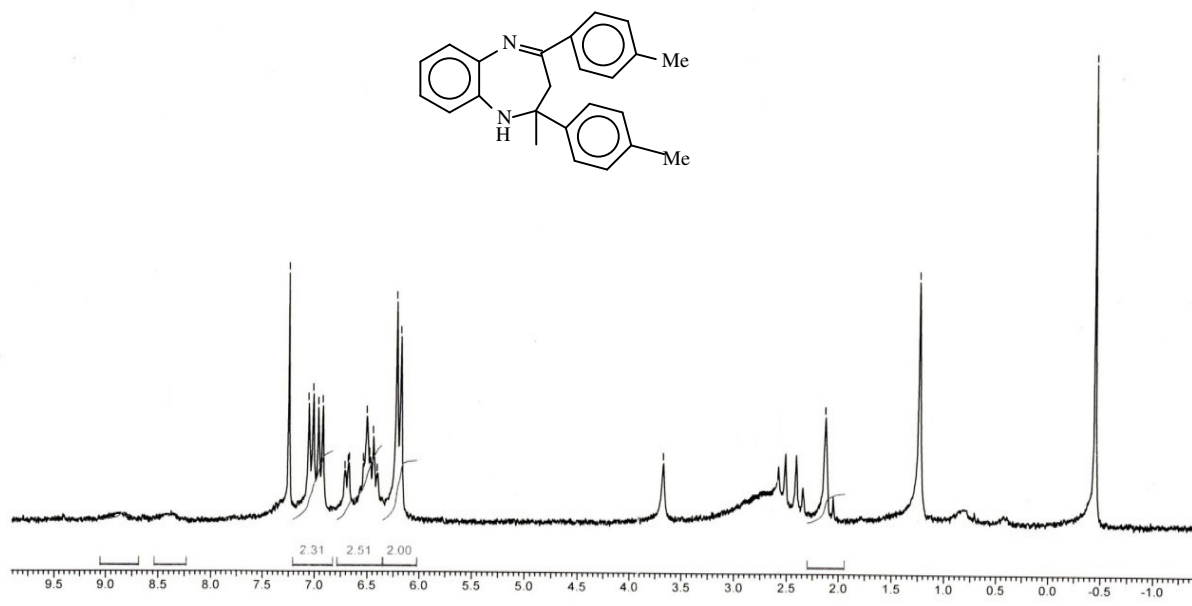

Figure 5. ${ }^{1} \mathrm{H}$ NMR spectra of (3g)

ФSHIMADZU

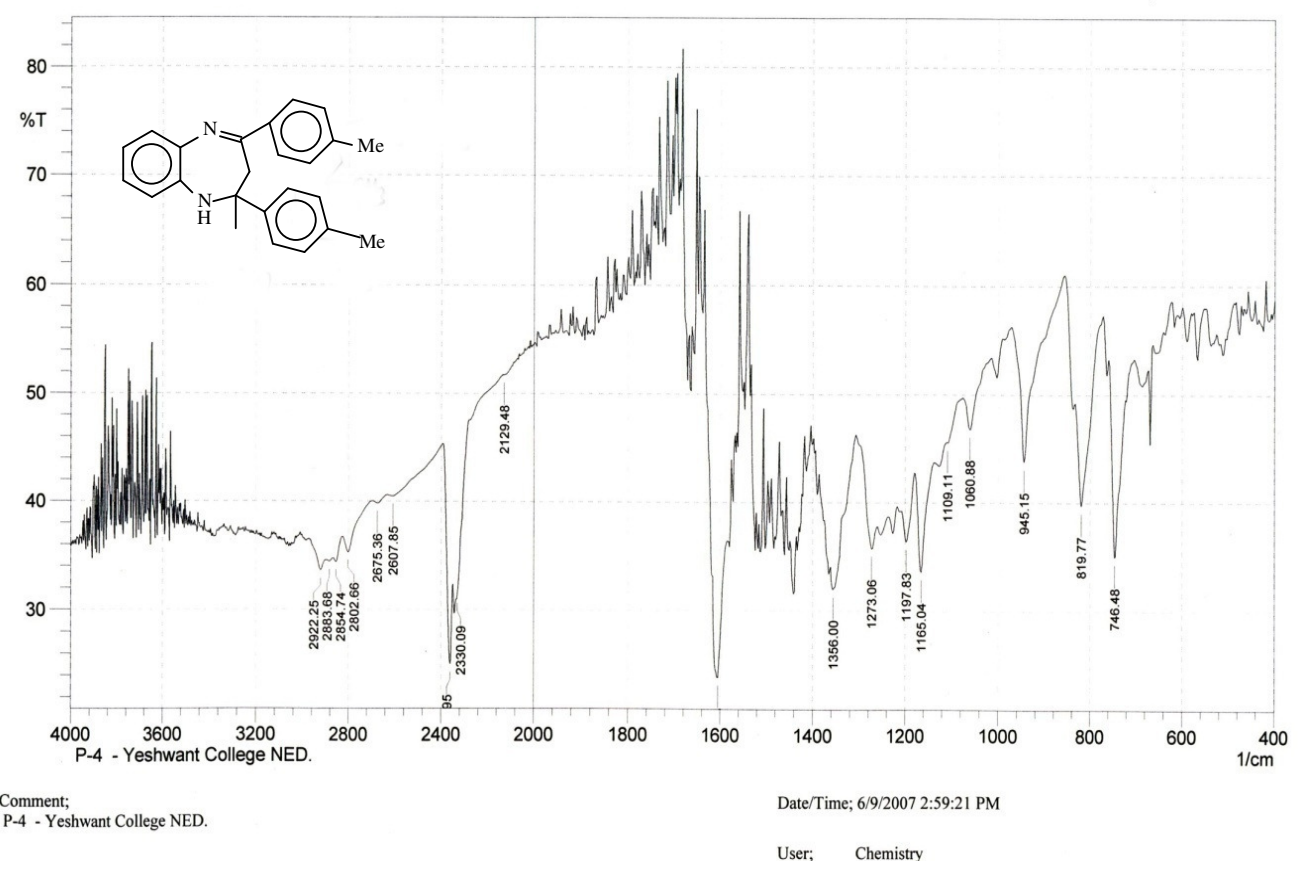

Figure 6. IR spectra of (3g) 


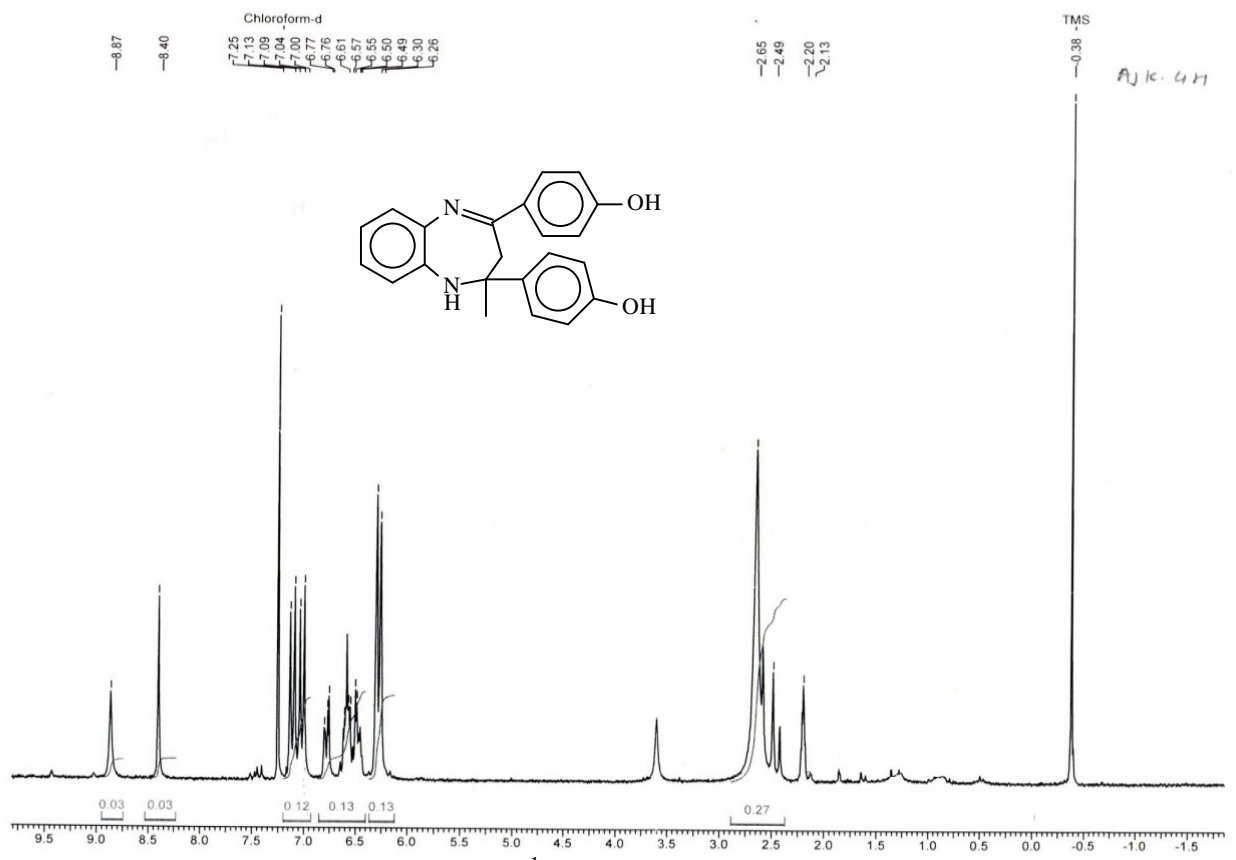

Figure7. ${ }^{1} \mathrm{H}$ NMR spectra of $(\mathbf{3 i})$

Spectral data for selected compounds

3a. IR (KBr): 3389, 2970, 1631,1591,1470,1100,744 $\mathrm{cm}^{-1} ; \mathrm{H}^{1} \mathrm{NMR}\left(\mathrm{CDCl}_{3}\right): \delta=1.1(\mathrm{~s}, 6 \mathrm{H})$,

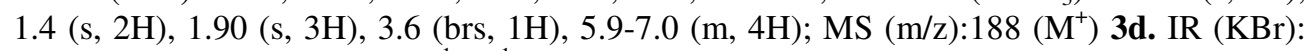
$3377,1664,1599,1440,750 \mathrm{~cm}^{-1} ; \mathrm{H}^{1} \mathrm{NMR}\left(\mathrm{CDCl}_{3}\right): \delta=0.7-1.5(\mathrm{~m}, 16 \mathrm{H}), 1.7-2.2(\mathrm{~m}, 3 \mathrm{H})$, 3.56 (brs, $1 \mathrm{H}), 6.1-7.0$ (m, 4H). 3f. IR (KBr): 3377, $1631 \mathrm{~cm}^{-1} ; \mathrm{H}^{1} \mathrm{NMR}\left(\mathrm{CDCl}_{3}\right): \delta=1.34$ (s, 3H), $2.2(\mathrm{~d}, 1 \mathrm{H}, \mathrm{J}=12.8 \mathrm{~Hz}), 2.4(\mathrm{~d}, 1 \mathrm{H}, \mathrm{J}=12.8 \mathrm{~Hz}), 3.6$ (brs, 1H), $7.7-7.1$ (m, 14H). 3g. IR (KBr): 2922, 1600, 1356,746 cm $\mathrm{cm}^{-1} \mathrm{H}^{1} \mathrm{NMR}\left(\mathrm{CDCl}_{3}\right): \delta=2.13(\mathrm{~s}, 6 \mathrm{H}), 1.24(\mathrm{~s}, 3 \mathrm{H}), 2.4$ $(\mathrm{d}, 1 \mathrm{H}, \mathrm{J}=6.9 \mathrm{~Hz}), 2.5(\mathrm{~d}, 1 \mathrm{H} \mathrm{J}=6.9 \mathrm{~Hz}), 3.67$ (brs, 1H), 6.0-6.66 (m, 4H), 6.72-7.2 (m, 8H); 3i. IR (KBr): $3377,1631,1440 \mathrm{~cm}^{-1} ; \mathrm{H}^{1} \mathrm{NMR}\left(\mathrm{CDCl}_{3}\right): \delta=1.3(\mathrm{~s}, 3 \mathrm{H}), 2.2(\mathrm{~d}, 1 \mathrm{H}), 2.49$ $(\mathrm{d}, 1 \mathrm{H}), 3.6(\mathrm{brs}, 1 \mathrm{H}), 8.4(\mathrm{~s}, 1 \mathrm{H}), 8.87(\mathrm{~s}, 1 \mathrm{H}), 6.3-6.7(\mathrm{~m}, 4 \mathrm{H}), 6.8-7.2(\mathrm{~m}, 8 \mathrm{H})$

\section{Conclusion}

We have developed a new, mild and efficient method for the synthesis of 1, 5-benzodiazepines. The workout procedure is easy, environmental friendly and inexpensive catalyst, short reaction time, reaction mild reaction conditions and in excellent yield.

\section{Acknowledgment}

The present study was sponsored by the University Grants Commission, New Delhi for which our gratitude is expressed. Authors also thankful to the Principal, Milliya College, Beed and Principal Yeshwant College, Nanded for providing all research facilities.

\section{References}

1 a) Schutz H, Benzodiazepines, Springer, Heidelberg, 1982, 2, 240; (b) Smalley R K, In Comprehensive Organic Chemistry. Barton D and Ollis W D, Eds., Pergamon, Oxford, 1979, 4, 600; (c) Landquist J K, In Comprehensive Heterocyclic Chemistry, Katritzky A R and Rees C W, Eds., Pergamon, Oxford, 1984, 1,166. 
2 Randall L O, Kappel B, In Benzodiazepines, Garattini S, Mussini E and Randall L O, Eds., Raven Press, New York, 1973, 27 and references cited therein. (b) Kuo C W, Wang C, Kavala V and Yao C F, Molecules, 2008, 13(9), 2313-2325.

3 Sternbach L H, Angew Chem Int Ed Engl., 1971, 10, 34.

4 (a) Atwal K S, Bergye J L, Hedberg A and Moreland S, J Med Chem., 1987, 30, 635-640;

(b) Braccio M D, Grassi G, Roma G, Vergin L, Mura M and Marongiu M, Eur J Med Chem., 2001, 36, 935; (c) Benedikta H H, Pudziunaite D, Janciene R and Kosychora L, Arkivoc., 2000, (iv), 512.

$5 \quad$ Harris R C and Straley J M, US Patent 1537, 753757, 1968; Chem Abstr., 1970, 73, $100,054 \mathrm{~W}$.

6 (a) Essaber M, Baouid A, Hasnaoui A, Benharref A and Lavergne J P, Synth. Commun., 1998, 28, 4097; (b) El-Sayed A M, Abdel-Ghany H and El-Saghier A M M, Synth Commun., 1999, 29, 3561; (c) Xu X J, Wu H T and Jin S, Chin J Chem., 1999, 17, 84, (d) Zhang X Y, Xu J X and Jin S, Chin J Chem., 1999, 17, 404; (d) Reddy K V V, Rao P S and Ashok D, Synth Commun., 2000, 30, 1825.

7 Stahlofen P and Ried W, Chem Ber., 1957, 90, 815-824.

8 Ried W and Torinus E, Chem Ber., 1959, 92, 2902.

$9 \quad$ Herbert J A and Suschitzky H, J Chem Soc Perkin Trans., 1974, 1, 2657.

10 Morales H R, Bulbarela A and Contreras R, Heterocycl., 1986, 24, 135.

11 Jung D I, Choi T W, Kim Y, Kim I S, Park Y M, Lee Y G, Jung D H, Synth Commun., 1999, 29, 1941-1951.

12 Balakrishna M S and Kaboudin B, Tetrahedron Lett., 2001, 42, 1127.

13 Curini M, Epifano F, Marcotullio M C and Rosati O, Tetrahedron Lett., 2001, 42, 3193-3195.

14 Yadav J S, Reddy B V S, Eshwaraian B and Anuradha K, Green Chem., 2002, 4, 592.

15 Yadav J S, Reddy B V S, PraveenKumar S, Nagaiah K, Lingaiah N and Saiprasad P S, Synthesis, 2004, 6, 901.

16 Reddy B M and Sreekanth P M, Tetrahedron Lett., 2003, 44, 4447.

17 Pozarentzi M, Stephanatou J S and Tsoleridis C A, Tetrahedron Lett., 2002, 43, 1755-1758.

18 Kumar R, Chaudhary P, Nimesh S, Varma A K and Chandra R, Green Chem., 2006, 8, 519 .

19 Varala R, Ramu E and Adapa S R, Arkivoc., 2006, (xiii), 171-177 and references cited therein.

20 Jarikote D V, Siddiqui S A, Rajagopal R, Daniel T, Lahoti R J and Srinivasan K V, Tetrahedron Lett., 2003, 44, 1835.

21 Yuying Du, Fuli T and Wenzhi Z, Synth Commun., 2006, 36, 1661. 


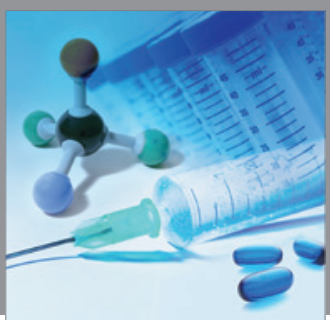

International Journal of

Medicinal Chemistry

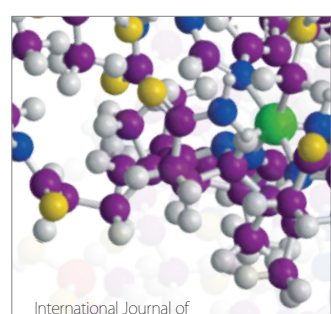

Carbohydrate Chemistry

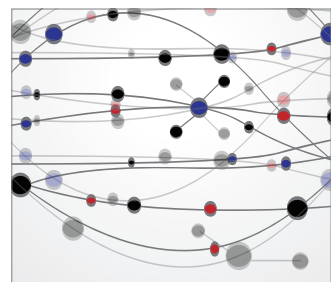

The Scientific World Journal
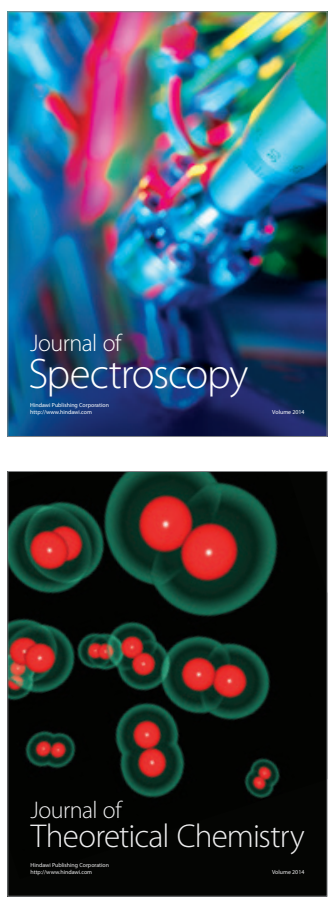
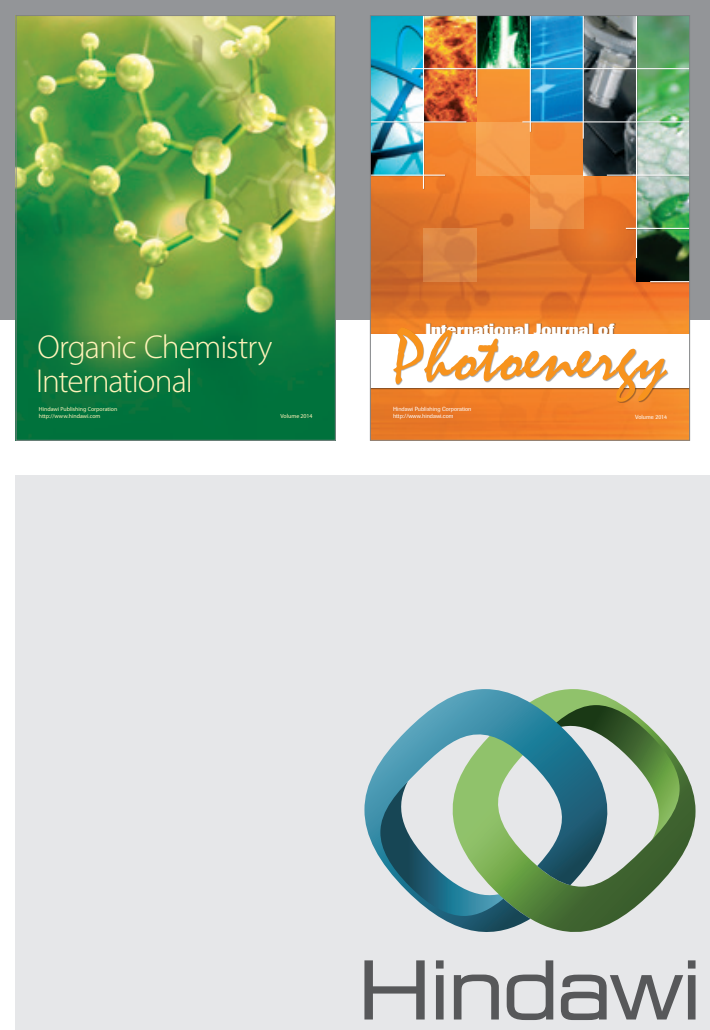

Submit your manuscripts at

http://www.hindawi.com
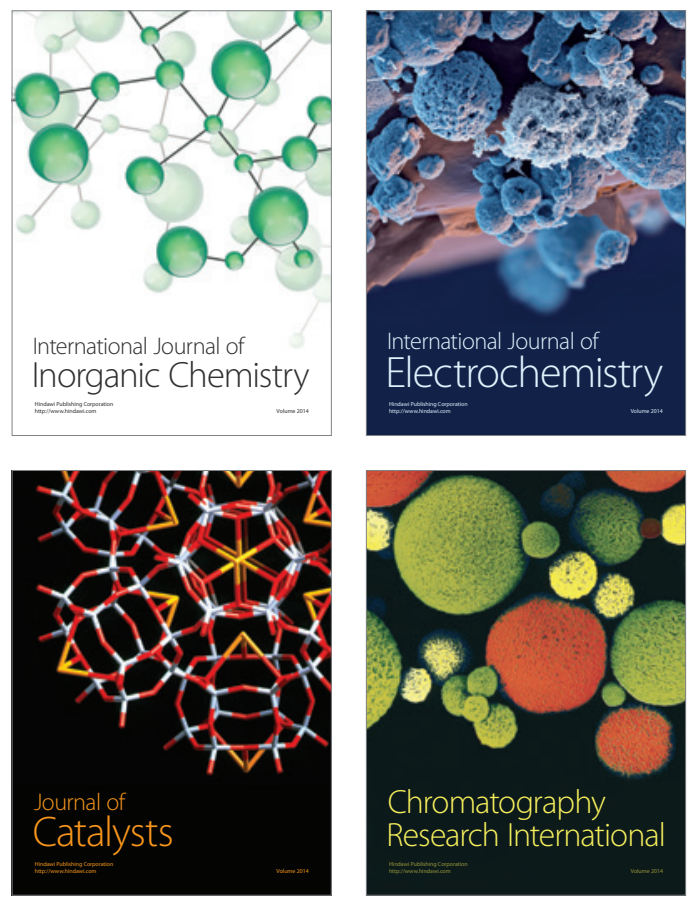
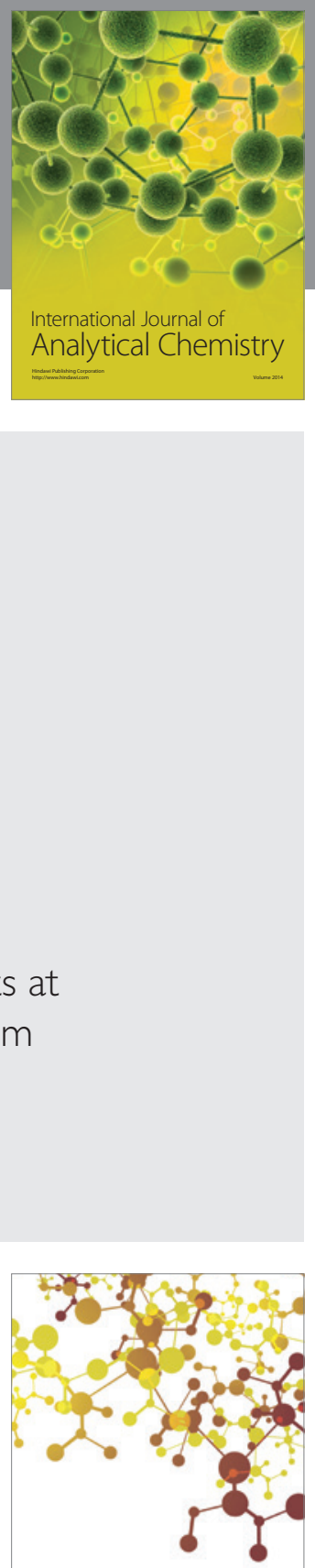

Journal of

Applied Chemistry
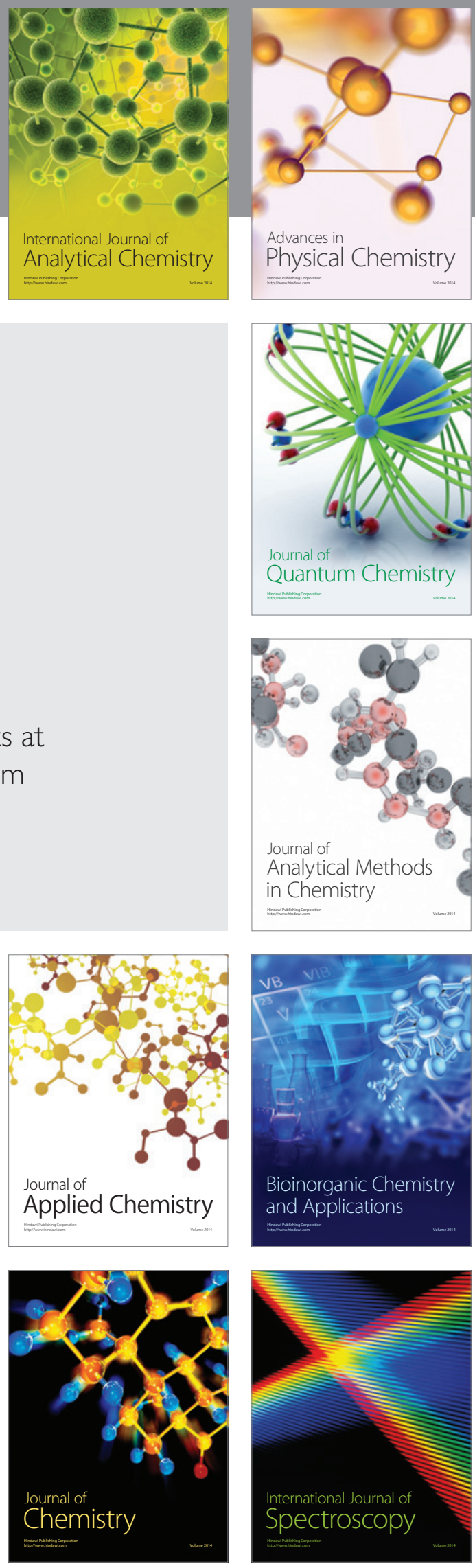